\title{
Development of Character-Based Instructional Model through Constructivism Approach in Lesson Study
}

\author{
Abdul Hasan Saragih \\ Educational Technology State University of Medan \\ Medan, North Sumatera, Indonesia \\ ahasansaragih@gmail.com
}

\begin{abstract}
The changes of educational paradigm that occur continuously should be responded by educators and education practitioners. This study aimed to develop a character-based instructional model through constructivism approach with the application of lesson study to improve student ability in instructional design. The development stage is carried out through: overviewing the learning activities to be developed, conducting a self-planning analysis, monitoring what is being planned in the learning activities, connecting the interrelationship of the instructional component with the objective to be achieved and evaluating the design of instructional by doing selfevaluation. The results of the research shows that observer and student responses, as well as product assessment results, structurally, character-based instructional model through constructivism approach is feasible, relevant, and in accordance with the rules of instructional, both in terms of substance, and model framework. The character-based instructional model through constructivism approach with the application of lesson study is effectively used to improve students ability in instructional design.
\end{abstract}

Keywords-component: instructional model, character, lesson study, constructivism

\section{INTRODUCTION}

The need for a new orientation in designing instruction feels so strong and real in many aspects with regard to the components and field of study. Educators and education practitioners should be able to respond the changes that occur in educational paradigm. One way to answer and overcome changes that occur continuously is to implement the model as an important reference of the implementation of instruction.

Based on the reality that exists so far in lectures of Instructional Design, there are some difficulty in making learning scenarios that can lead students to learn actively, innovatively and creatively. They do not realize that the design of instructional can not instantly imitate from others or take the finished ones because everything will take into consideration of conditions and characteristics of students encountered, and what patterns or strategies will be used. Therefore, the researcher who is also the lecturer of this course need to apply the lesson study program in the course of Instructional Design.

Problems in learning, among others: (1) The learning process that most teachers do is limited to providing knowledge of memorization, and less emphasis on high level cognitive aspects, such as the sharpness of the power of analysis and evaluation, the development of creativity, learning independence, and the development of affective aspects, students are passive; (2) Less oriented material; field of knowledge, field research, and longterm needs; (3) using learning patterns that tend to be the same from year to year. Curriculum changes do not have an impact on changing teaching materials, strategies, and learning media. (4) Learning competence is mostly limited to low level cognitive domain.

Some causes of low quality of instructional, among others due to: (1) teacher work alone in preparing and implementing instructional, and (2) teacher have a high ego, feel all-knowing, not easy to receive input for improvement of instructional. If the teacher is innovative in teaching, then the creativity does not affect other teachers because there is no sharing among teachers about the learning process. When creative teachers retire then their creativity goes away. Of course there is no perfect instructional model, there is always a gap for improvement. The mindset of such teachers needs to be improved so that teachers can collaborate and want to share with other teachers and be open to instructional improvement. Lesson study activities are an alternative to improving teachers' mindset in improving the learning process.

Instructional design is the process of developing various decisions that will be implemented during the learning activities to achieve the goal. A good planning will systematically assist teachers analysis student needs and developing possibilities solutions related to needs. Teacher that have a good instructional planning can project the activities of students to achieve learning objectives. A good instructional planning should contain five components called anchor points, namely: (1) The purpose of teaching; (2) Lesson material / teaching materials; (3) teaching approaches and methods, instructional media and learning experiences; (4) Tools / Media and Learning Resources; and (5) Evaluation of success [1]. 
Based on the experience of researchers in the last three years, there were still found some problems in the learning process so that the results obtained were not maximal. From the identification of problems among others it can be revealed that: (1). Students' learning activities were still low, (2) Some students still had difficulties in understanding the concepts and materials correctly, (3) Most students had not absorb and implement the values of characters that should be obtained.

Lesson study is not a strategy or method of instruction, but is one of the coaching efforts to improve the learning process conducted by a group of teachers in a collaborative and continuous, in planning, implementing, observing and reporting learning outcomes [2]. There are three main stages in lesson study activities, namely the stage plan (planning), do (implementation) or often also called the open class (open class), and see (reflection) [3]. In this paper it will be discussed activities at the time of plan (planning) only. Plan (planning) is an early stage in lesson study activities. At this stage it is done to design an Instructional Implementation Plan (RPP) which would be implemented as learning programs that have been decided in the syllabus.

Lesson study is a model of professional educator development through collaborative and continuous learning based on collegiality principles and mutual learning to build learning communities [4]. Lesson study is a model of professional education through collaborative learning and continuous learning based on the collegiality principles by a group of teachers to build a learning community. Lesson Study is not a strategy or learning method, but lesson study activities can apply various strategies and learning methods that can be adapted to the situation and conditions and problems faced by teachers (lecturers) in every learning process [5].

Lesson Study is "a model of professional educator building through collaborative and sustainable learning based on the collegiality principles and mutual learning to build learning communities" [6]. Learning Community in the school environment is done as an important concept in the development of school culture and quality. In the implementation, there are three stages to be done, namely plan (plan), do (perform), and see (reflect) [7]. The lesson study model has received much attention from teachers and education practitioners because it has strategic value in developing teacher professionalism. According to Cerbin \& Kopp [8], Lesson Study has 4 (four) main objectives: (1) Gain a better experience of how students learn and teach teachers; (2) Obtain certain outcomes utilized by other teachers, outside the lesson study participants; (3) Improve instructional systematically through collaborative learning; (4) Building a pedagogical knowledge, where a teacher can draw from other teachers [9].

Richardson [10] suggested the seven stages of the lesson study to improve the quality of teachers (who still resemble Lewis) namely; (1) forming a lesson study team; (2) focusing lesson study; (3) planning the lesson; (4) preparation for observation (5) carrying out its instructional and observation; (6) conducting learning discussions that have been implemented (reflection); (7) plan the instructional for the next stage. While Sagor's research [11] resulted in the finding that lesson study as a research involves three main stages: planning, implementation, reflecting / see.

The lesson study referred to in this study is a cyclical teacher training process, beginning with a teacher: (1) planning learning through academic exploration of teaching materials, strategies, and learning tools; (2) conducting lesson based on materials, strategies and lesson tools, inviting peers to observe; (3) reflect on the learning through discussion with the observer. Therefore, the implementation of the lesson study program needs to be monitored and evaluated so as to know the effectiveness, efficiency of learning. Lewis [12] suggests there are six stages in the beginning of implementing lesson studies in schools, namely (1) Forming lesson study groups (2) focusing lesson study (3) developing lesson plans (4) implementing learning in the classroom and observing (observation) (5) ) reflection and analysis the learning that has been implemented (6) plan the next stage of learning.

Character education is solely a part of good instructional and is a fundamental part of good education [13]. Character-based design instructional model with constructivist approach developed in this research is a conceptual framework that contains propositions as a guide for prospective teachers to design and implement learning activities. Therefore, the ideal character-based instructional model in accordance with the needs of students can be summarized as follows.

Character-based instructional design model with constructivist approach through the implementation of lesson study is a instructional model developed for prospective teacher students through the stages of planning, monitoring, and evaluation during the activities of the task of designing the design of instructional. The design of the ideal instructional model required by the students is a character-based instructional model constructive approach. The feasibility of the characterbased instructional model from the expert's point of view shows that the structure, the developed model undergoes significant change and development so it is feasible to be used for teaching planning lectures. The evaluation result from the team concludes that the model of character-based instructional model with constructivist approach is feasible, relevant, and in accordance with the rules of instructional model development, both in terms of substance, and model structure based on active student approach.

The importance of this research and development, then the effort should be done is the Development of Character Based Instructional Model Through Constructivism Approach In Lesson Study at course of Instructional Design. Through research and development it is very important to be done to develop instructional model of teaching planning. 


\section{METHOD}

This research uses research and development method which is carried out on the students of Mechanical Engineering Education and Automotive Engineering Education Program semester V at the course of Instructional Design.

The steps of the development of this instructional model was based on the results of document review and observation of the learning process. Both of these were required for document analysis. The development of this instructional model begins with preliminary research that was needs analysis. This needs analysis began from analysis of syllabus and RPP documents that lecturers make as a teaching guide. The analysis of the teaching and learning process was directed at the identification of the learning steps that were implemented by the students in the pursuit planning lecture. The instruments used in this preliminary study were the observation and questionnaire guidelines that had been evaluated by the expert with the target of providing information about the instructional components. Then synthesize information about the needs of the steps of designing instruction both from lecturers, and students. The output was a list of instructional components, needs analysis instruments, model characteristics used, and perceptions of the models available and which will be developed.

Validation, Evaluation, and Model Revision. A series of validation, evaluation, and revision of the model has been conducted in this study using several instruments; (1) Instruments. The instruments used in this study consist of questionnaires, observation guides, interview guides, and tests. Questionnaires were used to collect students' perceptions of the needs in the development of a character-based instructional model through constructivism approach in lesson study at course of instructional design. (2) Feasibility instruments both questionnaires and tests were used for different tests in order to determine the effectiveness of the application of instructional models, and have been validated prior to use. The validation results indicate that the questionnaire has been good for use with the re-formulation of several sentences and discarding the unnecessary parts; (3) Expert Review. The initial design of the instructional model is reviewed by experts / experts related to the field of instructional, language. After testing, the next step is to improve the model design in accordance with the data obtained from the initial test results. Expert advice and input were used for model refinement; (4) Product try out after the initial product was tested in an individual group, it was then refined according to the expert's cecommendation or suggestion. Furthermore, try out were conducted in the trial class group. This was done to improve the product; (5) Product Feasibility Test. Product feasibility had been tested through expert judgments, and students as potential users of the model. The product of feasibility test was carried out at the design test and product test stage using inference criteria based on the coefficient of agreement; and (6) Product Effectiveness Test. The product effectiveness has been tested through experiment in Class A of Mechanical Engineering Education Study Program and Class B of Automotive Education Study Program with 30 subjects of the experimental group, and piloted in comparison group without use of developed model.

Data, Data Source, Data Collection Technique, Data Analysis Technique; (1) Data and Data Source In this study there are two kinds of data, namely quantitative data, and qualitative data. Quantitative data in the form of scores of students' assessment of the criteria of need in instructional planning, assessment scores of respondents on the design of theoretical models developed, and data reading comprehension test scores. Qualitative data obtained from the observation of instructional, and the results of interviews with lecturers and students. The data needs of the character-based instructional model through constructivism approach in the lesson study obtained from the students through the questionnaire by survey method; (2) Data Collection Techniques in two ways: (a) document analysis from instructional design, and (b) distribution score from questionnaire.

Data analysis technique. In accordance with the stages in research and development, of course it have different goals and results, then the technique of data analysis were also various. To analyze the data of this research, there were two types of data, that is qualitative data and quantitative data. Qualitative data are: (1) data related to the general picture about character-based instructional model through constructivism approach in lesson study used by lecturer. This data is obtained from the analysis of documentation, observation of instructional activities undertaken, (2) responses of respondents / experts to the developed model. Quantitative data in the form of, (1) data relating to the needs of students obtained through the questionnaire, (2) data about the score of the ability to design the learning test. Furthermore, the respondent's data on characterbased instructional model through constructivism approach in lesson study were analyzed by researcher by two experts, i.e. expert in learning material and instructional design. Finally, the effectiveness of character-based instructional model through constructivism approach in lesson study was analyzed by statistics of t-test. This t-test was used to compare two average samples of the study. The basis of the assumptions used was that if the value of $t_{\text {count }}$ is greater than $t_{\text {table }}$ with the degree of freedom N-1 and the level of significance $\alpha=0.05$ indicates that the character-based instructional model through constructivism approach in the lesson study could effectively used.

\section{RESULTS}

More extensive trials to capture information in a wider range related to the quality of character-based instructional model through constructivism approach in lesson study, the subjects of this study are students. The data of the wider trial results by the students in each aspect can be seen in Table 1 below. 
TABLE 1. Data of feasibility test of character-based instructional model through constructivism approach in lesson study by students

\begin{tabular}{|l|l|c|c|}
\hline \multicolumn{1}{|c|}{$\begin{array}{c}\text { Assessment } \\
\text { Aspect }\end{array}$} & \multicolumn{1}{|c|}{ Description } & $\%$ & Criteria \\
\hline $\begin{array}{l}\text { Student learning } \\
\text { activities in the } \\
\text { presentation with } \\
\text { lesson study }\end{array}$ & $\begin{array}{l}\text { As a presentation of instructional } \\
\text { strategies and media prepared }\end{array}$ & 86,34 & $\begin{array}{l}\text { Very } \\
\text { feasible }\end{array}$ \\
\cline { 2 - 4 } & $\begin{array}{l}\text { As an audience that gives } \\
\text { invocation and reinforcement of } \\
\text { the dish }\end{array}$ & 88,56 & $\begin{array}{l}\text { Very } \\
\text { feasible }\end{array}$ \\
\hline $\begin{array}{l}\text { Development of } \\
\text { student character } \\
\text { in lesson study }\end{array}$ & $\begin{array}{l}\text { Confident, responsible, sportive, } \\
\text { open, passionate, cooperative, } \\
\text { respectful, hard working, curious, } \\
\text { creative, honest, innovative }\end{array}$ & 87,35 & $\begin{array}{c}\text { Very } \\
\text { feasible }\end{array}$ \\
\hline $\begin{array}{l}\text { Cognitive and } \\
\text { constructive } \\
\text { abilities }\end{array}$ & $\begin{array}{l}\text { Construct instructional process } \\
\text { and build student creativity } \\
\text { during lesson study }\end{array}$ & 87,23 & $\begin{array}{l}\text { Very } \\
\text { feasible }\end{array}$ \\
\hline & The average score is & 87,41 & \\
\hline
\end{tabular}

Result of assessment and response test to student overall hence concluded that percentage of mean value from every aspect of its valuation is $87,41 \%$. Where if the range is at a score of $81 \% \leq X \leq 100 \%$ then the tendency of the limited trial results is categorized as "very feasible".

As for the average percentage of the results of the assessment of experts ie learning materials experts, instructional design experts can be seen in Table 2 below.

TABLE 2. Data of feasibility test of character based instructional model through constructivism approach in lesson study by the experts

\begin{tabular}{|c|c|c|c|c|}
\hline $\begin{array}{c}\text { Assessment } \\
\text { Aspect }\end{array}$ & Description & The experts & $\%$ & Criteria \\
\hline \multirow{4}{*}{$\begin{array}{l}\text { Student } \\
\text { learning } \\
\text { activities in } \\
\text { the } \\
\text { presentation } \\
\text { with lesson } \\
\text { study }\end{array}$} & \multirow{2}{*}{$\begin{array}{l}\text { As a presentation of } \\
\text { instructional strategies } \\
\text { and media prepared }\end{array}$} & $\begin{array}{l}\text { Instructional } \\
\text { Design }\end{array}$ & 88,45 & $\begin{array}{c}\text { Very } \\
\text { feasible }\end{array}$ \\
\hline & & $\begin{array}{l}\text { Teaching } \\
\text { Material } \\
\text { Planning }\end{array}$ & 85.23 & $\begin{array}{c}\text { Very } \\
\text { feasible }\end{array}$ \\
\hline & \multirow{2}{*}{$\begin{array}{l}\text { As an audience that } \\
\text { gives invocation and } \\
\text { reinforcement of the } \\
\text { dish }\end{array}$} & $\begin{array}{l}\text { Instructional } \\
\text { Design }\end{array}$ & 86,56 & $\begin{array}{c}\text { Very } \\
\text { feasible }\end{array}$ \\
\hline & & $\begin{array}{l}\text { Teaching } \\
\text { Material } \\
\text { Planning }\end{array}$ & 86,23 & $\begin{array}{c}\text { Very } \\
\text { feasible }\end{array}$ \\
\hline \multirow{2}{*}{$\begin{array}{l}\text { Development } \\
\text { of student } \\
\text { character in } \\
\text { lesson study }\end{array}$} & \multirow{2}{*}{$\begin{array}{l}\text { Confident, } \\
\text { responsible, sportive, } \\
\text { open, passionate, } \\
\text { cooperative, } \\
\text { respectful, hard } \\
\text { working, curious, } \\
\text { creative, honest, } \\
\text { innovative }\end{array}$} & $\begin{array}{l}\text { Instructional } \\
\text { Design }\end{array}$ & 85,78 & $\begin{array}{c}\text { Very } \\
\text { feasible }\end{array}$ \\
\hline & & $\begin{array}{l}\text { Teaching } \\
\text { Material } \\
\text { Planning }\end{array}$ & 82,45 & $\begin{array}{c}\text { Very } \\
\text { feasible }\end{array}$ \\
\hline \multirow{2}{*}{$\begin{array}{l}\text { Cognitive and } \\
\text { constructive } \\
\text { abilities }\end{array}$} & \multirow{2}{*}{$\begin{array}{l}\text { Construct } \\
\text { instructional process } \\
\text { and build student } \\
\text { creativity during } \\
\text { lesson study }\end{array}$} & $\begin{array}{l}\text { Instructional } \\
\text { Design }\end{array}$ & 83,44 & $\begin{array}{c}\text { Very } \\
\text { feasible }\end{array}$ \\
\hline & & $\begin{array}{l}\text { Teaching } \\
\text { Material } \\
\text { Planning } \\
\end{array}$ & 86,89 & $\begin{array}{c}\text { Very } \\
\text { feasible }\end{array}$ \\
\hline \multicolumn{3}{|c|}{ The average score is } & 85,63 & $\begin{array}{c}\text { Very } \\
\text { feasible }\end{array}$ \\
\hline
\end{tabular}

The percentage of the average score from the assessment results during the limited trial in terms of each aspect is (1) Student learning activities in the presentation with lesson study percentage average $86.62 \%$ (2) Aspects of student character development in lesson study with percentage average $84.11 \%$ (3) aspects of cognitive and constructive abilities with an average percentage of $85.12 \%$, and (4) aspects as a whole with an average percentage of $85.63 \%$.

TABLE 3. Result of hypotheses testing feasibility of characterbased instructional model through constructivism approach in lesson study

\begin{tabular}{|c|c|c|c|c|}
\hline No & $\begin{array}{l}\text { Testing } \\
\text { Phase }\end{array}$ & Testing (\%) & $\begin{array}{c}\text { Eligibility } \\
\text { Criteria }\end{array}$ & Conclusion \\
\hline 1 & Expert Test & 88,67 & Very feasible & \multirow{4}{*}{$\begin{array}{c}\text { Product of } \\
\text { character-based } \\
\text { instructional model } \\
\text { through } \\
\text { constructivism } \\
\text { approach in lesson } \\
\text { study }\end{array}$} \\
\hline 2 & $\begin{array}{l}\text { Limited } \\
\text { Testing }\end{array}$ & 85,87 & Very feasible & \\
\hline 3 & Wider Test & 89,56 & Very feasible & \\
\hline & In average & 88,03 & Very feasible & \\
\hline
\end{tabular}

Based on the test results of normality of postest test data, both samples are normally distributed and have homogeneous variance, so the hypothesis testing can be applied by t-test. The hypothesis testing aimed to compare the result of group learning taught by using character-based instructional model through constructivism approach in lesson study than the taught group that did not use a character-based instructional model through constructivism approaches in the lesson study.

The results of hypothesis testing of product effectiveness are as follows: average grade of experimental class postest $62,53 \%$ and class completeness reach $87,5 \%$ from 30 student. While the average value of postest for control class $56.45 \%$ and class completeness reached $67.5 \%$ of 30 students. Data postest are normal and homogeneous distributed, with one-tail t-test with significance level of $\alpha=0.05$ can be seen from experimental class study result the higher mean value than control class, and experimental class result higher than the achievement of the control class. The experimental class has reached the grade mark of $85.45 \%$, while the control class has reached $67.5 \%$. 
TABLE 4. Test result of hypotheses of product effectiveness of character-basaed instructional model through constructivism approach in lesson study

\begin{tabular}{|l|c|c|c|l|}
\hline \multicolumn{1}{|c|}{ Data } & $\begin{array}{c}\text { Average } \\
\text { value }\end{array}$ & $\mathbf{t}_{\text {count }}$ & $\mathbf{t}_{\text {table }}$ & \multicolumn{1}{c|}{ Conclusion } \\
\hline $\begin{array}{l}\text { Postest } \\
\text { Experiments }\end{array}$ & $62,53 \%$ & & & $\begin{array}{l}\text { learning outcomes of } \\
\text { teaching plan using a } \\
\text { character-based } \\
\text { instructional model } \\
\text { through constructivism } \\
\text { approach in lesson study } \\
\text { are higher than those not } \\
\text { using the instructional } \\
\text { model. }\end{array}$ \\
\hline $\begin{array}{l}\text { Postest } \\
\text { Controls }\end{array}$ & $56,45 \%$ & 5,58 & 1,69 \\
\hline
\end{tabular}

From the table of percentile values for the distribution of $\mathrm{t}$ with level of significance $\alpha=0.05$ it is found the value of 1.69 while $t$ value from statistics is 5.58 . The fact that the value of $\mathrm{t}_{\text {count }}$ is greater than that of $\mathrm{t}_{\text {table }}$ means that the Ho is rejected. The $\mathrm{Ha}$ is accepted. This means the hypothesis stating the effectiveness of character-based instructional model is accepted. It implies that the achievement of students taught by using a character-based instructional model through constructivism approach is greater than that taught by the non-character based instructional model

\section{DISCUSSION}

Discussions were held between model lecturers and observers, after the completion of learning process. At first the model lecturer created impressions during the learning process, then it was followed by the observers. Observers presented their findings in the classroom in an honest and wise ways by which the learning process could be improved. Model lecturer was required to accept inputs from the observers for the improvements of instruction at the later stage. In principle, everyone involved in the study activities are expected to set up learning communities [14].

To be able to start lesson study activities there should be chages in teachers' attitudes covering:

(1) spirit of introspection to what has been done to the learning process. Questions raised are have I done good taeching?, and have I done my job as optimally as possible? The series of questions are answered honestly, and the answers to the questions will certainly encourage the process of searching ways to solve the deficiencies of the answer;

(2) courage to accept suggestions from others for selfimprovement;

(3) courage to acknowledge one's own faults;

(4) courage to acknowledge and use other people's ideas; and

(5) courage to provides honest and respectful inputs.

Lesson study activities aim to improve teacher professionalism through improved teaching and knowledge enhancement [15]. Observation of student learning activities, aims to determine the method of teaching or teaching by teachers to get students to learn or not, so that the observation of students can be used to correct and improve the instructional method used. Lesson study activities have a big impact for teachers, as evidenced by the increasing ability of teachers who have participated in lesson study activities in preparing the lesson plans by applying relevant instructional models, and be able to carry out lessons based on the RPP that has been made, and after following the training lesson study teachers are able to guide other teachers in planning and implementing lesson study [16].

Discussion Model of IPS teacher was based on lesson study in SMK Muhammadiyah Sukoharjo using "model of modification lesson study". This is in line with Stewart's research [17], entitled: A Model for Teacher Collaboration. Stewart's research shows that the best way to improve the positive improvement at every grade level in a school is to adopt a model (modify a model).

Meanwhile, Richardson [19] suggested 7 stages of lesson stady to improve the quality of teachers (who still resemble Lewis) namely (1) forming a lesson study team, (2) focusing lesson study, (3) planning learning, (4) preparing for observation, (5) ) carrying out the learning and observation (6) carrying out the learning discussions that have been implemented (reflection), and (7) planning the learning for the next stage. Urther, Sagor's study [18] finding indicated that lesson study as a research involves three main stages: planning, implementating and reflecting. .

Lecturers should continue to make improvements in the world of education by lifelong learning to be able to implement the seven elements of a contextual approach. The details of the seven elements are: (1) giving learners the chance to ask questions (2) applying authentic assessment during the learning process (authentic assessment), (3) training learners to model their friends, (4) training students to reflect, (5) forming a learning community by asking learners, (6) training students to construct their own learning concepts (constructivism), and (7) concepting that will be studied (inquiry).

\section{CONCLUSION}

The character-based instructional model through constructivism approach in lesson study developed in this research is derived from conceptual framework that contains propositions as a guide for prospective teachers to design and implement learning activities. Therefore, the character-based instructional model through constructivism approach in the lesson study is an ideal model with reference to the students' needs.

Instructional model developed is also advantegous for prospective teacher students. The design model is an ideal one required by the teacher students. The feasibility of the characterbased instructional model through constructivism approach in the lesson study from the expert's point of view indicates that structurally, the developed model undergoes significant change and development. The results of the evaluation from the expert 
team concluded that the character-based instructional model through constructivism approach in lesson study was feasible, relevant, and in accordance with the rules of instructional model development, both in terms of substance, and structure based on active student approach.

The application of lesson study gives a positive impacts on the student learning activities in the course of instructional design, encourages development of character and helps students in understanding the teaching materials planning concepts.

Lesson Study and the development of student learning community will increase the sense of togetherness and collegiality among fellow student prospective teachers. In practice by using the character as a part of planning, instructional and constructivist aspects are always emphasized to students in order to develop and construct better knowledge and insight.

\section{REFERENCE}

[1] Gagne', M. Robert. and L.J. Briggs, Principle of InstructionalDesign, second edition, New York: Holt Rinegart and Winston, 1979.

[2] Z. Siti. Lesson Study Sebagai Bentuk Program Continuing Professional Development (CPD) dan Peningkatan Pembelajaran Siswa. Jurnal JTEQIP, 2013, IV(2) hal. 103-118. Malang: UM.

[3] Syamsuri, Istamar dan Ibrohim. Lesson Study (Studi Pembelajaran). Malang: FMIPA UM, 2008.

[4] S. Hendayana, dkk. Lesson Study : Suatu Strategi untuk Meningkatkan Keprofesionalan Pendidikan (Pengalaman IMSTEP-JICA). Bandung : UPI Press, 2006, p. 10

[5] Rusman. Model-model Pembelajaran Mengembangkan Profesionalisme Guru. Jakarta: PT. Raja Grafindo Persada, 2011.
[6] S. Hendayana, dkk. Lesson Study : Suatu Strategi untuk Meningkatkan Keprofesionalan Pendidikan (Pengalaman IMSTEP-JICA). Bandung : UPI Press, 2006

[7] Rusman. 2011. Model-model Pembelajaran Mengembangkan Profesionalisme Guru. Jakarta: PT. Raja Grafindo Persada

[8] W. Cerbin, and B. Kopp, Lesson Study a Model For Building Pedagogical Knowledge and Improving Teaching. International journal of teaching and learning in higher education, 2006, 18 (3): 250-257

[9] A. Sudrajat, Lesson Study untuk Meningkatkan Proses dan Hasil Pembelajaran" onlinehttp://akhmadsudrajat.wordpress.com/2008/02/22/ diakses tanggal 08 Maret 2017

[10] J. Richardson. Lesson study: Teacher Learn How to Improve Instruction. Nasional Staff Development Council. (Online): www.nsdc.org. 03 mei 2017

[11] R. Sagor, How to Conduct Collaborative Action Research. Association for Supervision and Curriculum Development. Alexandria, 1992.

[12] Lewis, C. Catherine. Lesson study: A Handbook of Teacher-Led Instructional Change. Philadelphia, PA: Research for Better Schools, Inc, 2002.

[13] M. Samani,. dan Hariyanto. 2011. Konsep dan Model Pendidikan Karakter. Bandung: PT. Rosdakarya Remaja, 2011.

[14] Rusman. Model-model Pembelajaran Mengembangkan Profesionalisme Guru. Jakarta: PT. Raja Grafindo Persada, 2011.

[15] W. Cerbin, and B. Kopp, B.. Lesson Study a Model For Building Pedagogical Knowledge and Improving Teaching. International journal of teaching and learning in higher education, 2006, 18 (3): 250-257

[16] S. Mulyana, S. Dampak Pendidikan Dan Pelatihan Lesson Study Terhadap Guru-Guru. Artikel Hasil Penelitian. LPMP Jawa Barat, 2008.

[17] R. Stewart, J. Brederfur, J.. Fusing Lesson Study and Aithetic Achievent. Bloomington: A. Model for Teacher Collabooration. www.proquest.umi.com, 2005.

[18] R. Sagor, How to Conduct Collaborative Action Research. Association for Supervision and Curriculum Development. Alexandria, 1992.

[19] J. Richardson J. Lesson study: Teacher Learn How to Improve Instruction. National Staff Development Council. (Online): www.nsdc.org. 03 mei 2017 